\title{
Salt-stress-induced changes in protein profiles in two blackgram (Vigna Mungo L.) varieties differing salinity tolerance
}

\begin{abstract}
Two preselected blackgram (Vigna mungo L.) varieties differing salinity tolerance were treated with varying levels of $\mathrm{NaCl}(0,150$ and $225 \mathrm{mM})$ under greenhouse condition. The result showed that 'U-Taung-2' had significantly higher leaf, shoot, and root biomass than 'Mut Pe Khaing To' at 21days after treatment (DAT). Total proteins were extracted from leaves of control and $\mathrm{NaCl}$ treated plants after 10, 14 and 21 DAT and analyzed by sodium dodecyl sulfate-polyacrylamide gel electrophoresis (SDS-PAGE). Exposure of salt stress altered the protein profiles and promoted the accumulation of salt-specific proteins was depended on genotypes, the salt concentration and salt treatment duration. The changes of protein profiles in response to salinity stress were not detected in both varieties on 10 DAT. After 14 and 21 DAT, the accumulation of newly synthesized protein bands apparently molecular weight $(30,20$ and $18 \mathrm{kDa})$ were appeared as a result of $\mathrm{NaCl}$ treatments only in salt tolerant genotype, 'U-Taung-2', while this was not the case in salt-sensitive 'Mut Pe Khaing To' plants. It was suggested that appearance of synthesized proteins in response to $\mathrm{NaCl}$ treatments on 14 and 21 DAT of salt tolerant, 'U-Taung-2' plants might be related with the capability of metabolism to adjust or adapt to varying requirements in response to $\mathrm{NaCl}$ treatments and may be involved in osmotic adjustment.
\end{abstract}

Volume 7 Issue I - 2017

\author{
Khin Thuzar Win, Aung Zaw Oo \\ Tokyo University of Agriculture and Technology, Japan
}

Correspondence: Khin Thuzar Win, Tokyo University of Agriculture and Technology, Saiwaicho 3-5-8, Fuchu, Tokyo, I838509, Tel +8|4-236-758-78, Email khinthuzarwin@gmail.com

Received: March 30, 2016 | Published: April 05, 2017

Keywords: blackgram, salinity, growth, protein profile, SDS-PAGE

\section{Introduction}

Salinity is becoming a global issue due to climate changes. Currently, more than 800 million hectares of land throughout the world are affected by levels of salt that could substantially reduce crop productivity. ${ }^{1}$ It is also an enormous production problem for vegetable crops as saline conditions are known to suppress plant growth under irrigation. ${ }^{2}$ One approach to the problem in salt affected areas is to grow salt-tolerant species. ${ }^{3}$ The genotypes that can perform better than current varieties under salt stress condition would be beneficial for growers in salt affected areas. Salt stress leads to a series of morphological, physiological, biochemical and molecular changes that adversely affect plant growth and productivity. Adaptation to salt stress is a complicated process, at both the whole plant and cellular levels, and requires alterations in gene expression that lead to changes in the protein profile. ${ }^{4}$ Changes in proteins and other cellular components for plant acclimation to salt stress largely depend on the salt concentration, salt treatment duration and plant species. There are multiple genes that seem to act in concert to increase $\mathrm{NaCl}$ tolerance and certain proteins involved in salinity stress protection have been recognized. ${ }^{5,6}$ The tolerance to salt stress is accompanied by alterations in the level of proteins. The extensive studies revealed on changes in protein expression as a result of various abiotic stresses such as heat, cold, salt and heavy metals. ${ }^{7}$ Biochemical genetic marker such as SDS-PAGE was substantially involved in drought and salinity stresses. ${ }^{8}$ A number of studies indicated that several salt-induced proteins have been identified in plants species. ${ }^{9-13}$

Therefore, the examination of salinity tolerant and sensitive genotypes of blackgram ${ }^{14}$ was undertaken to elucidate if any polypeptides whose levels are perturbed with different levels of salt are related to such a tolerance. The objective was to identify varietaland treatment-specific alterations in the protein complement, and to exploit these as potential candidate protein involved in conferring salinity tolerance in blackgram.

\section{Materials and methods}

\section{Plant materials and growth conditions}

Two blackgram (Vigna mungo) varieties, salt-tolerant 'U-Taung-2' and salt-sensitive 'Mut Pe Khaing To', were used. ${ }^{14}$ Seeds were surface sterilized by soaking in $70 \%$ ethanol for 5 minutes and then in $2.5 \%$ sodium hypochlorite solution for 30 seconds. Once drained, the seeds were rinsed 5times with sterile distilled water. Then, seeds were planted in $3 \mathrm{~L}$ plastic pots $(20 \mathrm{~cm}$ diameter) containing $3 \mathrm{~kg}$ of the sample soil. For optimum growing of blackgram, experimental pots were placed in an artificial climate chamber at $30^{\circ} \mathrm{C} / 25^{\circ} \mathrm{C}$; day $/$ night, $12 \mathrm{~h}$ light, $60 \% \mathrm{RH}$, and photosynthetic active radiation (PAR) of $500 \mathrm{mmol}$ photons m-2s-1 at Tokyo University of Agriculture and Technology, Tokyo, Japan. After 7days of growth, plants were thinned to three uniform plants per pot. The seedlings were subjected to $\mathrm{NaCl}$ stress by moving into full-strength Hoagland solution with 0 (control), 150 and $225 \mathrm{mM}$ of $\mathrm{NaCl}$ for 21 days when the plants were 15 days old. Each pot was irrigated once per alternate day with above solution. The amount of solution added on each occasion was $500 \mathrm{ml}$ per pot, and was always introduced in the form of a soft pour from the edge of the pot in order to avoid contamination of plant parts. The nutrient solution comprised $4.0 \mathrm{mM} \mathrm{Ca}\left(\mathrm{NO}_{3}\right)_{2}, 4.0 \mathrm{mM} \mathrm{KNO}_{3}, 1.0 \mathrm{mM} \mathrm{MgSO}_{4}, 1.0 \mathrm{mM}$ $\mathrm{NH}_{4} \mathrm{H}_{2} \mathrm{PO}_{4}, 1.0 \mathrm{mM}\left(\mathrm{NH}_{4}\right)_{2} \mathrm{HPO}_{4}, 1 \mathrm{mMNaCl}, 41.2 \mu \mathrm{M}$ FeNaEDTA, $12.5 \mu \mathrm{M} \mathrm{H}_{3} \mathrm{BO}_{3}, 0.39 \mu \mathrm{M} \mathrm{CuSO}_{4}, 1.59 \mu \mathrm{M} \mathrm{MnSO}_{4}, 1.0 \mu \mathrm{M} \mathrm{ZnCl}_{2}$, and $0.5 \mu \mathrm{M} \mathrm{NaMoO}_{4}$. The $\mathrm{pH}$ of the nutrient solution was adjusted to 6.0 
with $0.1 \mathrm{mM} \mathrm{KOH}$ during the entire growing period. Then protein extraction was conducted on time course (10,14 and 21 DAT). Plants were harvested $21 \mathrm{DAT}$ and leaves, shoots, and roots were oven-dried at $80^{\circ} \mathrm{C}$ for $48 \mathrm{~h}$ and dry weight was determined.

\section{Preparation of total protein}

For SDS-PAGE, the uppermost fully expanded leaves (about $2 \mathrm{~g}$ of fresh weight) of both cultivars from control and salt stress conditions were ground to powder under liquid nitrogen in a chilled glass mortar and pestle and melted in ice-cold extraction buffer. Total protein extracts were prepared by extracting appropriate portion of the frozen plant material with $0.1 \mathrm{M}$ Tris $\mathrm{HCl}(\mathrm{pH}=8.8)$ and Tris $\mathrm{HCl} 0.625 \mathrm{M}$. All extracts were kept for $24 \mathrm{~h}$ at $4^{\circ} \mathrm{C}$ and then centrifuged at 14,000rpm for $25 \mathrm{~min}$. The supernatants were kept at $-20^{\circ} \mathrm{C}$ and then used for electrophoresis.

\section{Gel electrophoresis}

SDS Polyacrylamide Gel Electrophoresis (PAGE) was carried out with gel slabs (11.25\%) according to the method of Laemmli. ${ }^{15}$ Equal amount $(150 \mu \mathrm{g})$ of protein was loaded in each well. Two separate gels were run under similar electrophoretic conditions in order to check the reproducibility of the method. The molecular weights of the dissociated polypeptides were determined using molecular weight protein standards (MW-SDS-70 kit; Sigma, U.S.A.). Protein subunit bands were stained with Coomassie blue R-250 by standard techniques. The gel was scanned using Gel-Pro-Analyzer.

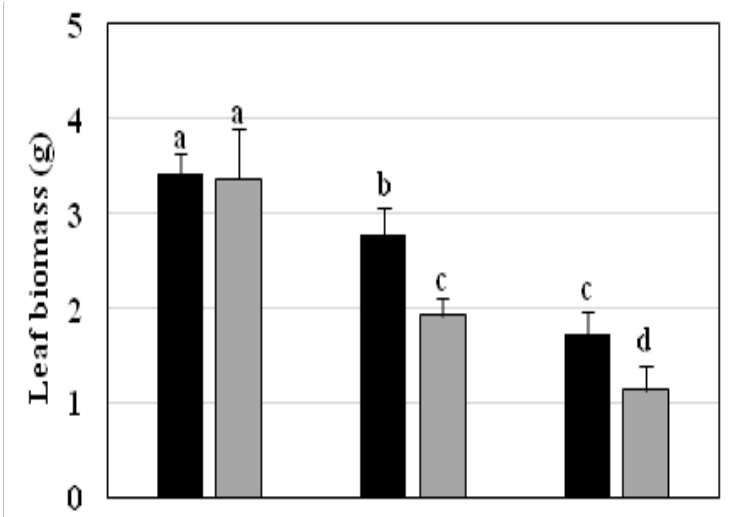

(A)

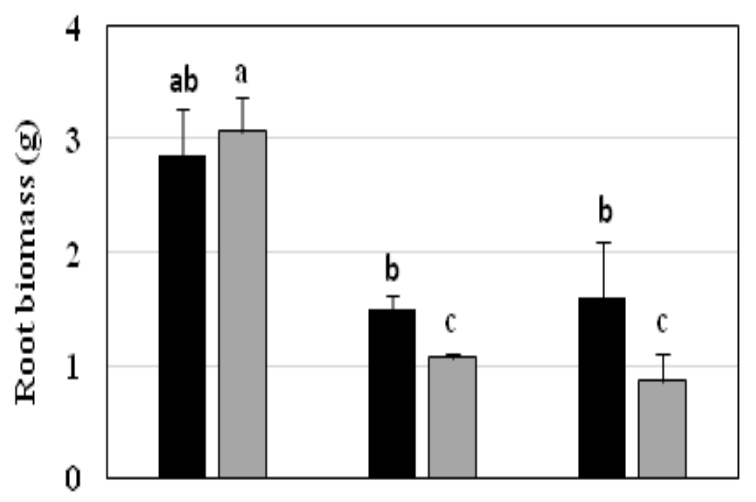

(C)

\section{Statistical analysis}

Analysis of variance was performed for all measurements with the CropStat version 7.0 software (International Rice Research Institute, IRRI, Philippines). The results were subjected to a two-way analysis of variance, and mean values were then compared by Tukey's honest significant difference $(\mathrm{HSD})$ test $(p<0.05)$ using XLSTAT Version 2010 (Addinsoft). Regression analyses among the parameters studied were calculated by using Sigma Plot 11.0 software (Systat Software, Inc., 2008).

\section{Results}

\section{Biomass}

Leaf, shoot, and root growths (Figure 1) were inhibited by increased salt treatments in both cultivars, although 'U-Taung-2' was more salt-tolerant than 'Mut Pe Khaing To'. The decreases in leaf, stem and root were 19,51 and $47 \%$ in 'U-Taung-2' in response to $150 \mathrm{mM} \mathrm{NaCl}$ stress, whereas 43, 67 and $65 \%$ were found in 'Mut Pe Khaing To' when compared with their respective controls with $0 \mathrm{mM}$ $\mathrm{NaCl}$, respectively. The reduction in these growths was increased with increasing salinity. In $225 \mathrm{mM} \mathrm{NaCl}$ treatment, the reduction of leaf, shoot, and root biomass per plant of 'U-Taung-2' were 50, 75, and $40 \%$ that of controls, while 'Mut Pe Khaing To' presented values of 67,81 , and $72 \%$ that of controls. Shoot dry weight per plant was most affected by salt in both cultivars. In both salt treatments, 'U-Taung-2' had significantly higher leaf, shoot, and root biomass than 'Mut Pe Khaing To'.

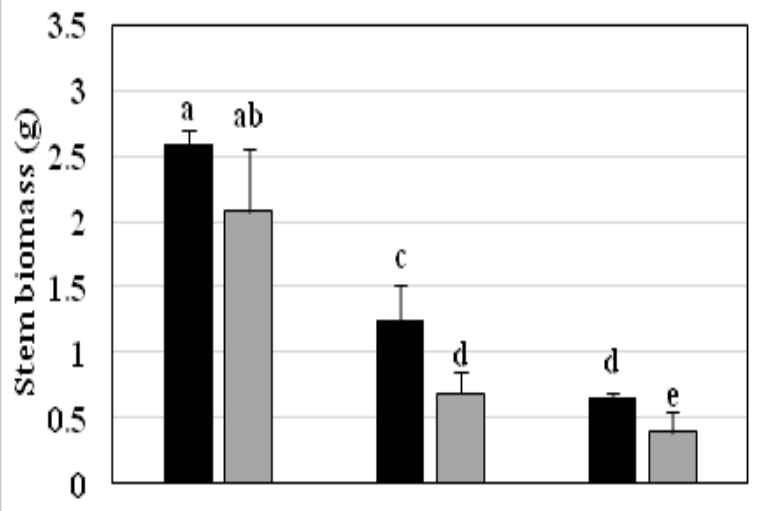

(B)

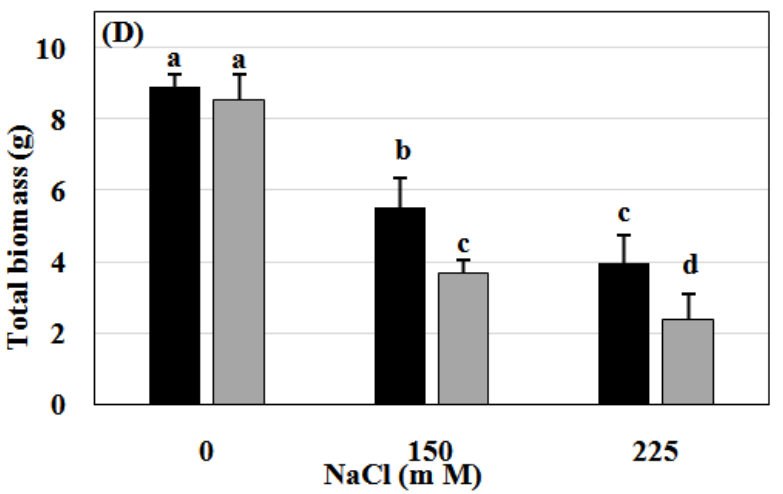

(D)

Figure I (A) Leaf biomass, (B) stem biomass, (C) root biomass and (D) total biomass of two blackgram varieties grown under 0 , I 50 and $225 \mathrm{mM} \mathrm{NaCl}$. Error bars indicate standard deviation $(n=3)$. In the same column, values followed by the same letter are not significantly different at the $5 \%$ level by Tukey's HSD test. (Black bars represent ' $U$-Taung-2' and gray bars represent 'Mut Pe Khaing To'). 


\section{Changes of protein profiles on IO DAT}

The electrophoretic patterns in leaves of ' $\mathrm{U}$-Taung-2' and 'Mut Pe Khaing To' plants grown under $\mathrm{NaCl}$ treatment and control condition were observed on 10 DAT (Figure 2). The pattern bands of apparently molecular weight $45 \mathrm{kDa}$ on the gels were stained more intensely in both varieties. No accumulation of synthesized protein bands were detected in both varieties in response to $\mathrm{NaCl}$ treatments with 150 and $225 \mathrm{mM} \mathrm{NaCl}$.

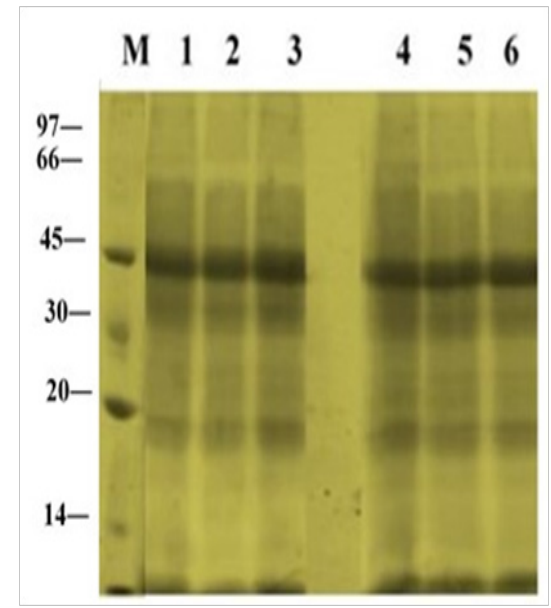

Figure $\mathbf{2}$ Changes in total protein profile in leaves of two blackgram varieties, salt-tolerant 'U-Taung-2' and salt-sensitive 'Mut Pe Khaing To' on I0 DAT. Lane M was protein marker. Lane I, 2 and 3 represent 'U-Taung-2' plants treated with 0,150 and $225 \mathrm{mM} \mathrm{NaCl}$, respectively. Lane 4,5 and 6 represent 'Mut Pe Khaing To' plants treated with 0,150 and $225 \mathrm{mM} \mathrm{NaCl}$, respectively.

\section{Changes of protein profiles on I 4 DAT}

Changes in total protein profiles in leaves of 'U-Taung-2' and 'Mut Pe Khaing To' plants after 14 DAT were observed (Figure 3). For 'U-Taung-2', accumulation of protein bands were detected at apparently molecular weight $(30,20$ and $18 \mathrm{kDa})$ and band intensity of apparently molecular weight $45 \mathrm{kDa}$ were stained more in response to 150 and $225 \mathrm{mM} \mathrm{NaCl}$ treatments when compared with control's bands. For 'Mut Pe Khaing To', no accumulated protein bands were detected by $\mathrm{NaCl}$ treatments whereas some band patterns apparently molecular weight $(30,20$ and $18 \mathrm{kDa})$ were diminished under salt stress conditions when compared to control plants.

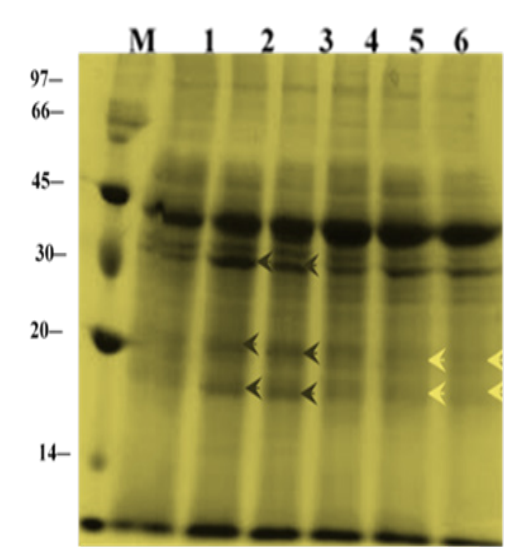

Figure 3 Changes in total protein profile in leaves of two blackgram varieties, salt-tolerant 'U-Taung-2' and salt-sensitive 'Mut Pe Khaing To' on I 4 DAT. Lane $M$ was protein marker. Lane I, 2 and 3 represent ' $U$-Taung-2' plants treated with 0, 150 and $225 \mathrm{mM} \mathrm{NaCl}$, respectively. Lane 4, 5 and 6 represent 'Mut Pe Khaing To' plants treated with 0,150 and $225 \mathrm{mM} \mathrm{NaCl}$, respectively.

\section{Changes of protein profiles on 2 I DAT}

'Mut Pe Khaing To' showed some death leaves on the lower parts of the plants whereas the 'U-Taung-2' signed still green leaves almost all parts of the plants. In ' $U$-Taung-2' plants treated with 0 and $150 \mathrm{mM} \mathrm{NaCl}$, protein bands apparently molecular weight at $(30,20$ and $18 \mathrm{KDa}$ ) were difficult to be detected. In contrast, 'U-Taung-2' plants treated with $225 \mathrm{mM} \mathrm{NaCl}$, a group of polypeptide at apparently molecular weight (20 and $18 \mathrm{kDa}$ ) was still detected and accumulation of band intensity at approximately molecular weight $(45 \mathrm{kDa})$ was still accumulated more when compared with control's bands (Figure 4). In 'Mut Pe Khaing To', apparently molecular weight at 30, 20 and 18 proteins could not be detected in both 150 and $225 \mathrm{mM} \mathrm{NaCl}$ treatments when compared with its control plants. The intensity band at $(45 \mathrm{kDa})$ was decreased in response to $\mathrm{NaCl}$ treatments.

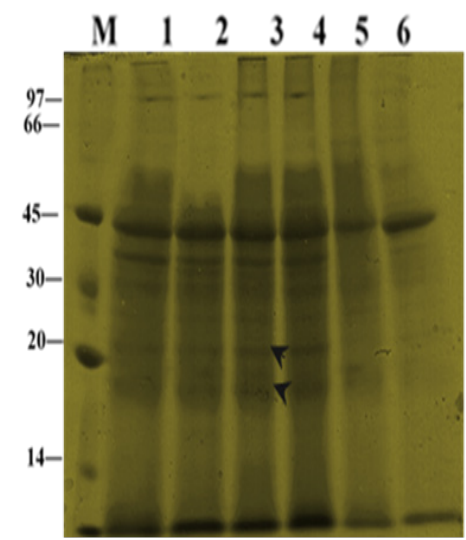

Figure 4 Changes in total protein profile in leaves of two blackgram varieties, salt-tolerant 'U-Taung-2' and salt-sensitive 'Mut Pe Khaing To' on 2 I DAT. Lane $M$ was protein marker. Lane I, 2 and 3 represent ' $U$-Taung-2' plants treated with 0 , I 50 and $225 \mathrm{mM} \mathrm{NaCl}$, respectively. Lane 4, 5 and 6 represent 'Mut Pe Khaing To' plants treated with 0 , I 50 and $225 \mathrm{mM} \mathrm{NaCl}$, respectively.

\section{Discussion}

Salinity is a major environmental factor that limits plant growth and crop productivity, ${ }^{16}$ and different crops may have varying salt-tolerant mechanisms. 'U-Taung-2'and 'Mut Pe Khaing To', two blackgram cultivars, both showed evident inhibitions of growth under salt stress. It has been observed that shoots had considerably greater reductions in growth than roots and leaves. Under both $\mathrm{NaCl}$ concentrations, 'U-Taung-2' exhibited better salt tolerance, and consequently, less growth reduction than 'Mut Pe Khaing To' (Figure 1). It is well established that salt tolerance and sensitivity depend on the genetic and biochemical composition of the species. Plants growing in saline environments show distinct changes in the pattern of synthesis and accumulation of proteins. Salinity causes either decrease or increase in the level of soluble proteins or completely disappears in some proteins when compared to the control treatment. ${ }^{17}$ In addition, salt stress promotes the synthesis of newly formed proteins. ${ }^{17}$ Furthermore, salt tolerance and salt sensitive genotypes have different patterns of protein profiles. ${ }^{18,19}$ This led us to suggest that protein bands accumulation can be used as an indicator in selection for salt tolerant cultivars since it provided some of the most cost-effective tools for data point generation.

In the present study, accumulation of newly synthesized proteins has been detected in 'U-Taung-2' plants in response to $\mathrm{NaCl}$ stress on 14 and 21 DAT, whereas it was not in 'Mut Pe Khaing To' plants (Figure 3), (Figure 4). Our results indicated that increasing of protein 
band patterns exposed to salt stress is relatively genotype dependent; salt induced protein bands accumulation between $(45-30 \mathrm{kDa}$ and $30-18 \mathrm{kDa}$ ) appeared only in salt tolerant variety. This result is in agreement with those of Abdel-Haleen ${ }^{20}$ who reported an increase in protein band which might be involved in mungbean tolerance. Bishnoi et al., ${ }^{21}$ also reported the appearance of $95.6 \mathrm{kDa}$ proteins in plumule and $67.5 \mathrm{kDa}$ proteins in the radicle of Manak (salt-tolerance) under $\mathrm{NaCl}$ treatment with no specific protein in IEPL 88039 (saltsensitive). The number of induced proteins in response to salinity stress was greater in the tolerant variety than in the sensitive. These differences could be associated with the biochemical adjustment of the plants to cope up with the saline conditions. ${ }^{22}$ Such proteins were involved in increasing plant adaption to salt stress and might play a role in tolerance, however direct evidence is generally lacking. ${ }^{23}$ By comparing the leaf protein electrophoresis profiles of a salt-tolerant and a salt-sensitive genotype, proteins bands at apparently $(30,20$ and $18 \mathrm{kDa}$ ) showing a cultivar-specific or a stress related expression were detected in 'U-Taung-2' plants under 150 and $225 \mathrm{mM}$ of $\mathrm{NaCl}$ stress on 14 and 21 DAT. However, interestingly it was noticed that accumulation of these new proteins in 'U-Taung-2' also dependent on time sequences; salt-related expression has not yet started and still unchanged under salinity condition when compared with controls on 10 DAT. Ben-Hayyim et al., ${ }^{24}$ suggested that its salt-induced accumulation in the cells was also relatively slow and gradually increased during a period of severaldays following exposure of the cells to $\mathrm{NaCl}$.

Since, water relation mechanism and some physiological processes were already happened under salinity on $10 \mathrm{DAT} .{ }^{14}$ It was suggested that the expression of the salinity associated proteins were probably accumulated after short-term salinity stress (after 10 DAT). These proteins might be involved in defending the $\mathrm{NaCl}$ stress or adaptation/ adjustment of stress environment. Ricard et al. ${ }^{25}$ proposed that the increase in the number of bands in salinity treatments indicates that salinity stress may promote synthesis of some proteins, which probably acts as an osmoticant. This was coincidence with our previous study, the decreases in osmotic potential was more notable in 'Mut Pe Khaing To' plants when compare with 'U-Taung-2' plants showing a lesser decrease in leaf water potential under a short-term salinity stress. ${ }^{26}$ Although, the precise mechanism involved in the response of these salt-induced proteins and relationship with water relation mechanism remains unknown, we suggested that these proteins might be involved in osmotic adjustment when the plants were subjected to water shortage due to $\mathrm{NaCl}$ stress. $\mathrm{ABA}$ being accelerated in osmotic adjustment and the role of ABA in salt tolerant and sensitive blackgram varieties might be beneficial to comparison of protein expression to salt stress. This topic remains to be investigated in the future.

\section{Conclusion}

Identification of protein markers for stress tolerance could provide a simple and inexpensive tool to plant breeders for analyzing tolerance trait in the segregation population of a cross between salt tolerant and sensitive cultivars. It also provided information regarding salt induced polypeptides which could be utilized for screening tolerant cultivars. Our studies indicated that salt tolerance and salt sensitive varieties showed similar biochemical reaction at protein level in short term exposure to $\mathrm{NaCl}$ treatments (10 DAT). It is suggested that both varieties might not have no specific adaptation to salt stress at the level of proteins occurs in the short term stress (10 DAT). Appearance of synthesized proteins in response to $\mathrm{NaCl}$ treatments on 14 and 21 DAT of 'U-Taung-2' plants might be related with the capability of metabolism to adjust or adapt to varying requirements in response to $\mathrm{NaCl}$ treatments. In this context, the expression of $\mathrm{NaCl}$ specific proteins in the tolerant blackgram variety 'U-Taung-2' under salinity stress is an important feature of this investigation pointing to underlying molecular events right up to the genomics. It was suggested that salinity induced proteins could be used as a better index in blackgram under salt stress conditions. Further characterization of these proteins might help in identification of exact genetic domain responsible.

\section{Acknowledgements}

None.

\section{Conflict of interest}

The author declares no conflict of interest.

\section{References}

1. Munns R, Tester M. Mechanisms of salinity tolerance. Annu Rev Plant Biol. 2008;59:651-681.

2. Parida AK, Das AB. Salt tolerance and salinity effects on plants:a review. Ecotoxicol Environ Saf. 2005;60(3):324-349.

3. Win KT, Oo AZ. Genotypic difference in salinity tolerance during early vegetative growth of cowpea (Vigna unguiculata L. Walp.) from Myanmar. Biocatal Agric Biotechnol. 2015;4:449-455.

4. Parker R, Flowers TJ, Moorem AL, et al. An accurate and reproducible method for proteome profiling of the effects of salt stress in the rice leaf lamina. J Exp Bot. 2006;57(5):1109-1118.

5. Bohnert HJ, Jensen RG. Metabolic engineering for increased salt tolerance-the next step. Aust J Plant Physiol. 1996;23(5):661-667.

6. Hare PD, Du Plessis S, Cress WA, et al. Stress induced changes in plant gene expression. S Afr J Sci. 1996;92:431-439.

7. Grover A, Pareek A, Satya-Lakshmi O, et al. Understanding molecular alphabets of the plant abiotic stress responses. Curr Sci. 2001;80(2):206216

8. Rahman AEMF, Ansary AL, Rizkalla AA, et al. Micropropagation and Biochemical Genetic Markers detection for Drought and Salt Tolerance of Pear Rootstock. Aust J Basic Appl Sci. 2007;1(4):625-636.

9. Elavumoottil OC, Martin JP, Moreno ML. Changes in sugars, sucrose synthase activity and proteins in salinity tolerant callus and cell suspension cultures of Brassica oleracea L. Biol Plant. 2003;46(1):7-12.

10. Sreenivasulu N, Grimm B, Wobus U, et al. Differential response of antioxidant compounds to salinity stress in salt tolerant and salt sensitive seedling of foxtail millet (Setaria italica). Physiol Plant. 2000;109(4):435-442.

11. Mansour MMF. Nitrogen containing compounds and adaptation of plants to salinity stress. Biol Plant. 2000;43(4):491-500.

12. Ali G, Srivastava PS, Iqbal M. Proline accumulation, protein pattern and photosynthesis in Bacopa moniera regenerants grown under $\mathrm{NaCl}$ stress. Biol Plant. 1999;42(1):89-95.

13. Hurkman WJ, Fornari CS, Tanaka CK. A comparison of the effect of salt on polypeptide and translatable mRNA in roots of a salt tolerant and salt sensitive cultivar of barley. Plant Physiol. 1989;90(4):1444-1456.

14. Win KT, Oo AZ, Ookawa T, et al. Changes in hydraulic conductance cause the difference in growth response to short-term salt stress between salt-tolerant and-sensitive black gram (Vigna mungo) varieties. J Plant Physio. 2016;193:71-78. 
15. Laemmli UK. Cleavage of structural proteins during the assembly of the head of bacteriophage T4. Nature. 1970;227(5259):680-685.

16. Asish KP, Anath BD. Salt tolerance and salinity effects on plants:a review. Ecotoxicol Environ Saf. 2005;60(3):324-349.

17. Yıldız M. Two-dimensional electrophoretic analysis of soluble leaf proteins of a salt sensitive (Triticum aestivum) and a salt-tolerant (Triticum durum) cultivar in response to $\mathrm{NaCl}$ stress. J Integr Plant Biol. 2007;49(7):975-981.

18. Witzela K, Matrosa A, Strickerta M, et al. Salinity stress in roots of contrasting barley genotypes reveals time-distinct and genotype-specific patterns for defined proteins. Mol Plant. 2014;7(2):336-355.

19. Rani M. Influence of salinity on metabolic status of proteins and amino acids during germination and early seedling stages of rice. Ph.D Thesis, India: Banras Hindu University; 1988. p. 180-191.

20. Abdel-Haleen MA. Physiological Aspects of Mungbean Plant (Vigna radiata L.Wilczek) in Response to Salt Stress and Gibberellic Acid Treatment. Res J Agr Biol Sci. 2007;3(4):200-213.
21. Bishnoi SK, Kumar B, Rani C, et al. Changes in protein profile of pigeonpea genotypes in response to $\mathrm{NaCl}$ and boron stress. Biol Plant. 2006;50(1):135-137.

22. Mahmoodzadeh H. Protein profiles in response to salt stress in seeds of Brassica napus. Res J Environ Sci. 2009;3(2):225-231.

23. Goncalo A, Filho S, Ferreira BS, et al. Accumulation of SALT protein in rice plants as response environmental stresses. Plant Sci. 2003;164:623628.

24. Ben-Hayyim G, Faltin Z, Gepstein S, et al. Isolation and characterization of salt-associated protein in Citrus. Plant Sci. 1993;88 129-140.

25. Ricard B, Cauee I, Raymond P, et al. Plant metabolism under pypoxia and anoxia. Plant physiol Biochem. 1996;32:1-10.

26. Win KT. Classification and characterization of Vigna species in view of salinity tolerance. PhD thesis of United Graduate School of Agriculture. Japan: Tokyo University of Agriculture and Technology; 2012. 